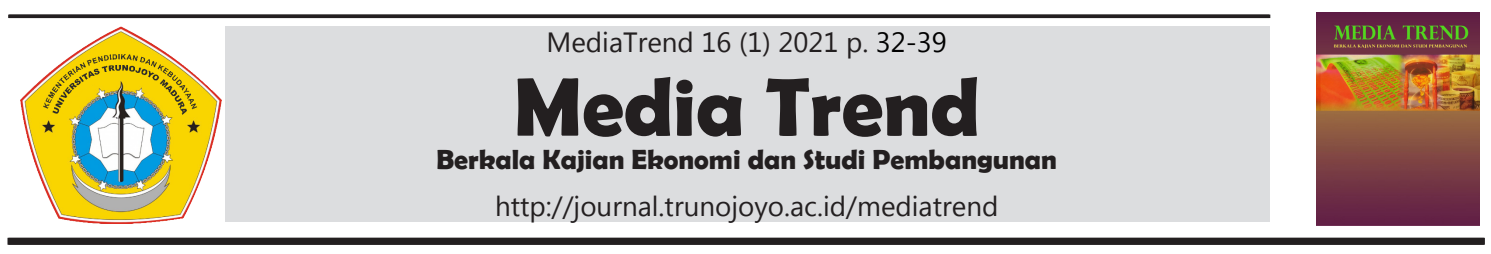

\title{
Causality Between Higher Education With Economic Growth In Indonesia
}

\author{
Triyani $^{1^{*}}$, Tri Haryanto ${ }^{2}$
}

${ }^{1,2}$ Airlangga University

\section{Article Information}

History of article:

Received July 2020

Approved February 2021

Published March 2021

\begin{abstract}
A B S T R A C T
The aim of this study is to investigate the causality between higher education and economic growth in Indonesia in 1980-2017. The econometric approach of this study used the Vector Auto Regressive (VAR) and Granger Causality Test. The Empirical results show evidence of unidirectional causality between higher education and economic growth in lag 1 with $\alpha$ of 10\%. These results indicate that education as a form of investment in human resources will affect the economy. This study also shows that economic growth does not affect higher education. This unidirectional causality can be explained that the economic growth that occurs does not directly increase the overall income of the community, meaning that the positive impact of growth can only be enjoyed largely by a group of high-income people.
\end{abstract}

Keywords: Causality, VAR, Education, Economic Growth, Indonesia.

JEL Classification Code: $\mathrm{I} 21, \mathrm{O} 47, \mathrm{C} 22$ 


\section{INTRODUCTION}

The achievement of high economic growth is the goal of every country. These efforts require resource support. One of the resources that affect economic growth is human resources (Apergis \& Poufinas, 2020). The role of human capital in increasing economic growth basically comes from the assumption of the Solow growth model which incorporates technological advances to optimize labor. Solow's growth theory by explaining the role of the power of accumulated knowledge and technological assets as a source of growth that comes from domestic strength (endogenous factors) (Salman et al., 2019). Endogenous Growth Model and Solow Growth Model, enabling each country to optimize internal strength (endogenous) in the form of the ability to master science combined with natural resources, savings rates, population growth, and technological advances as sources of growth.

Human capital (human capital) with a level of knowledge and skills which is one of the sources of economic growth and a source of competitiveness (competitiveness) of a country. The concept of humancapital is defined as the knowledge and skills, ideas or ideas, information and health conditions possessed by individuals. The important role of human capital as one of the drivers of sustainable development can be seen from its long-term contribution to the productivity of individuals or workers (Truong et al., 2021). The high productivity of workers will be able to increase high economic growth.

Analysis of the contribution of human capital to economic growth can be viewed from a micro and macroeconomic perspective. The microeconomic point of view sees the role of human capital as a part of production input in addition to other inputs such as physical capital, labor, and technology which are manifested in the form of quality Human Resources (Kruss et al., 2015). The production process, which uses quality labor input both in knowledge and skills, will have an impact on competence, mastery of labor technology, and the emergence of new innovations so that in the end it can encourage efficiency and productivity (Marginson, 2018).

Indonesia as a developing country still faces the quality of its human resources. Indonesia's Human Development Index (HDI) in 2017 reached 70.81. Based on these achievements, Indonesia is in the 116th position out of 189 countries in the world. Furthermore, based on the Global Competitive Index (GCl) 4.0, Indonesia's competitiveness is ranked 36th out of 137 countries. HDI and Indonesia's competitiveness have improved, but are still low in terms of innovation, technology adaptation, and labor market efficiency which are closely related to the achievement of the education sector.

One example of research conducted by Solaki (2013) resulted in the growth of real GDP per capita in Greece from changes in primary education, secondary education, higher education and expenditures in the education sector. Pelinescu (2014) conducted research in European countries and Wang et al (2016) in 55 countries from 5 continents during the period 1960-2009. The conclusion shows that human capital, proxied by education and health indicators, has a significant positive effect on economic growth (GDP growth).

A case study that discusses the study of how the relationship between human capital and economic growth between regions in Indonesia was carried out by Saepudin (2013). The results of the research analysis state that the growth in human capital which is proxied by the number of high schools and university graduates has a positive and significant effect on economic growth between regions 
in Indonesia, as well as the effect of growth in government spending in education on economic growth between regions. Also states that the difference in economic growth in developed countries with developing countries is caused by $80 \%$ of the influence of physical capital and human capital, while the remaining $20 \%$ is due to other factors.

Another study on the influence and relationship between human capital and economic growth in terms of patterns of mutual influence (cointegration) or a causality between variables has been conducted by Mariana (2015), namely analyzing the causal relationship between education and economic growth. The education variable proxied by the number of students enrolled in higher education and expenditure in education, meanwhile, the economic growth variable proxied by the Gross Domestic Product (GDP) per capita in Romania for the 1980-2013 period. The results of a study conducted by Mariana (2015) concluded that education has a positive effect on economic growth and both have a long-term relationship (cointegration).

The existence of conditions in Indonesia related to the problem of imbalance between the development process and efforts to improve the qualit of human capital, especially output in higher education, thus encouraging research on the relationship or reciprocal relationship (causality) between economic growth and higher education as an aspect of human capital in Indonesia. The focus of this research is on higher education because it is based on the fact that higher education has a major role in providing educated personnel, the accumulation of technology-based knowledge capital, and innovation as a stimulus foreconomic growth and national development (agent of economic development) in an effort to increase the nation's competitiveness.

\section{METHODOLOGY}

This study aims to look at the long-term relationship between higher education and economic growth as well as the causality between higher education and economic growth in Indonesia. The first step in this research is to perform a unit root test. This test is carried out to see the stationarity of the variables used, whether the data is stationary or not. The second step is to perform a cointegration test, if the two variables are integrated, then the possibility of a long-term balance between the observed variables will occur.

The procedure to determine whetherthe data is stationary or not is by comparing the ADF statistical value with the critical value of the Mackinnon statistical distribution. If the absolute value of the ADF statistic is greater than the critical value, then the observed data shows stationary and vice versa, if the absolute value of the ADF statistic is smaller than the critical value, then the data is not stationary.

In the ADF test, if the conclusion is that the data is not stationary, then steps are needed to make the data stationary through the data differentiation process. The stationary test of data through this differentiation process is called integration test. The degree of integration test used is Augmented Dickey-Fuller. As with the previous unit root test, the decision to what degree a data will be stationary can be seen by comparing the ADF statistical value with the critical value of the Mackinnon distribution. If the absolute value of the ADF statistic is greater than the critical value at the first level of differentiation, then the data is said to be stationary at level one. However, if the value is smaller, then the integration degree test needs to be continued at a higher differentiation so that it is stationary.

This study uses a quantitative approach, an approach that focuses on testing and proving hypotheses through 
various tests using measured data and calculations accompanied by an explanation of the results of the calculations. This study aims to see the causality between higher education institutions and economic growth by using a time series Vector Auto-Regressive (VAR) analysis for the period 1980 - 2017 and the Granger Causality Test. The VAR model is built with the consideration of minimizing theoretical approaches to be able to capture economic phenomena. Therefore, the VAR model is a non-theoretical time series model.

The most important thing in VAR estimation is the problem of determining the lag length in the VAR system. The optimal length of the variable inaction is needed to capture the effect of each variable on other variables in the VAR system. Determination of the optimal lag length can use several criteria such as Akaike Information Criterion (AIC), Schwartz Information Criteria (SIC), Hannan-Quin Criteria (HQ), Likelihood Ratio (LR), and Final Prediction Error (FPE). The optimal lag length occurs if the criteria value above has the smallest absolute value.

The cointegration test is the next stage of the unit root test and the degree of integration. Cointegration test to test and estimate the long-term relationship between the economic variables studied. The cointegration test can be done by compiling a long-term equation first to obtain the residual value, which is then tested at the degree level with the ADF test. If a stationary residual value is obtained, then there is a long-term balance between the independent and dependent variables in the model. This method is often called the Augmented Engle-Granger (AEG) cointegration test method.

The Granger Causality Test is a method to determine where the dependent variable can be influenced by othervariables and vice versa, and the independent variable can occupy the position of the dependent variable (Mazzarisi et al., 2020). This relationship is called a causal or reciprocal relationship. The result of Granger causality will produce four possibilities, namely one-way causality from $x$ to $y$, one-way causality from $y$ to $x$, two-way causality from $x$ to $y$, and $y$ to $x$, and not. there is causality between variables (Vaduva et al., 2020).

The research variables used were the number of students and economic growth. Both of these variables cannot be identified as independent variables or dependent variables so that all variables are considered as dependent variables. These variables can be determined after the Granger causality test is carried out. The model used to determine whether there is a causal relationship between proxies of higher education and the number of students and economic growth in Indonesia is as follows:

$$
\begin{aligned}
& L n H E_{t}=\sum_{j=1}^{m} a_{j} L n H E_{t-j}+\sum_{j=1}^{n} b_{j} G E_{t-j}+u t \\
& G E_{t}=\sum_{j=1}^{o} c_{j} G E_{t-j}+\sum_{j=1}^{p} d_{j} L H E_{t-j}+v t
\end{aligned}
$$

where LHEt is number of students in year $t$ (natural logarithm), Get is economic growth in year $t$, LnHEt-j: the number of students lag operation, GEt-j is economic growth lag operations, $t$ is time, $\mathrm{j}$ is time lag, aj, bj, cj, dj is regression coefficient, ut and vt is error term. Higher Education is the number of enrolled students (school enrollment) in units of people. Economic growth is the process of increasing Indonesia's Gross Domestic Product (GDP) in percentage.

The data used in this study are secondary data that is time series with a time of 1980 - 2017. The data used in this study are the number of registered students obtained from the Ministry of Research, TechnologyandHigherEducationand Gross Domestic Product (GDP) Indonesia. 


\section{RESULTS AND DISCUSSION}

The dynamics of tertiary institutions in Indonesia are experiencing increasingly advanced developments. Higher education has an important role in every activity carried out by the government or the state. Higher Education in Indonesia at the beginning of its development was carried out by the Directorate General of Higher Education, Ministry of Education and Culture. Government policies prioritize aspects of sustainable development that encourage the greater role of higher education as part of the determining elements of development success. This is in accordance with the policy outlined by the Ministry of Education and Culture in 1975.

The role of higher education as a provider of skilled and skilled personnel to carry out economic development. In line with the policy that has been issued, efforts to increase the establishment of new colleges or study programs that are relevant to the needs of the community are also continuously carried out by the government, both universities managed by the government, namely State Universities (PTN) and universities that are managed and organized. by the community, namely private universities (PTS).

Economic growth is a condition of an increase in output that lasts in the long run and shows the success of a country in providing various needs for goods for its citizens. Efforts to create high economic growth are basically the efforts of a country in managing and utilizing its resources to produce output in the long term in line with technological advances and the institutional conditions experienced.

Indonesia as a country that has natural resources and human resources as well as other potential development capital has also experienced dynamics of economic growth in several periods since the old order government to the present. The ups and downs of the dynamics of Indonesia's economic growth can be divided into the pre-reform era, namely the period 1945-1998 and the reform era from 1999 to the present.

Table 1

Stationary Test

\begin{tabular}{|l|c|c|}
\hline Variabel & $I(0)$ & $I(1)$ \\
\hline LnHE & 0,9618 & 0,0000 \\
\hline GE & 0,0010 & 0,0000 \\
\hline
\end{tabular}

Table 1 shows that the higher education variable (LnHE) is not stationary at I (0), but the economic growth variable (GE) is stationary at the level level. Higher education is not stationary at the level level because the ADF probability values are more than $1 \%, 5 \%$, and $10 \%$, so it is not stationary. Furthermore, the first difference or I (1) process shows that all variables are stationary, because the ADF probability of the two variables is less than $1 \%, 5 \%$, and $10 \%$. All variables are stationary in I (1), then they are not affected by unit root problems. 
Table 2

Lag Length Criteria Test

\begin{tabular}{|c|c|c|c|c|c|c|}
\hline \multicolumn{7}{|c|}{ VAR Lag Order Selection Criteria } \\
\hline \multicolumn{7}{|c|}{ Endogenous varlables: YGROWTH D(ENROLL) } \\
\hline \multicolumn{7}{|c|}{ Exogenous variables: $\mathrm{C}$} \\
\hline \multicolumn{7}{|c|}{ Sample: 19702018} \\
\hline \multicolumn{7}{|c|}{ Included observations: 44} \\
\hline Lag & LogL & LR & FPE & AIC & SC & $\mathrm{HQ}$ \\
\hline 0 & -175.5392 & NA & 10.95968 & 8.069961 & $8.151061^{\prime}$ & $8.100037^{\prime \prime}$ \\
\hline 1 & -170.2681 & $9.786003^{*}$ & $10.35607^{*}$ & $8.013097^{*}$ & 8.256395 & 8.103323 \\
\hline 2 & -169.2374 & 1.862684 & 11.86237 & 8.147154 & 8.552651 & 8.297532 \\
\hline 3 & -163.9203 & 9.942294 & 11.21201 & $\mathrm{~B}, 09728 \mathrm{~B}$ & 8,654996 & $\mathrm{~B} .297818$ \\
\hline 4 & -161.5313 & 3.800714 & 12.13952 & 8.160515 & 8.890410 & 8,431195 \\
\hline \multicolumn{7}{|c|}{ 'indicales lag order selected by the crilerion } \\
\hline \multicolumn{7}{|c|}{ LR: sequentlal modifled LR test statistic (each test at $5 \%$ level) } \\
\hline FPE: FIr & rediction errc & & & & & \\
\hline \multicolumn{7}{|c|}{ AIC: Akaike information criterion } \\
\hline \multicolumn{7}{|c|}{ SC: Schwarz information critterion } \\
\hline \multicolumn{4}{|c|}{ HQ: Hannan-Quinn information crilerion } & & & \\
\hline
\end{tabular}

The estimation results in Table 2 show the lag used to analyze the causality test. The selected lag is lag 2 with the AIC approach. This is because AIC provides the lowest score compared to other approaches.

Table 3

Granger Causality Test Results

\begin{tabular}{|c|c|}
\hline Variabel & Prob \\
\hline LnHE $\rightarrow \mathrm{GE}$ & 0,0984 \\
\hline GE $\rightarrow$ LnHE & 0,4965 \\
\hline
\end{tabular}

Based on the Granger causality test, the results show that there is a unidirectional causality, namely higher education affects economic growth at the $\alpha$ level by $10 \%$. These results indicate that education as a form of investment in human resources will affect the economy. This means that economic growth depends on human capital. The results of this estimate support that education is proven to have an effect on driving economic growth. Human Capital Theory states that education has a positive influence on economic growth. Humans who have higher levels of education and have better skills will have jobs and be followed by better wages than workers with lower education. If wages reflect the level of productivity, then an increase in the number of highly educated workers means a higher contribution to productivity which in turn will encourage aggregate growth.

Education has a significant positive effect on growth as evidenced in several empirical studies. Kesikoglu and Ozturk (2013) proved in their study that there was a bi-directional causality between the costs of the education sector and economic growth in 20 groups of OECD countries during the 1999-2008 period. Investments in human capital embodied in the education sector have had a positive impact on growth in these countries. Pelinescu (2014) conducted research in European countries and Wang et al (2016) in 55 countries from 5 continents during the period 19602009. The conclusion shows that human capital, proxied by education and health indicators, has a significant positive effect on economic growth (GDP growth). 
The results of data estimation from this study also indicate that economic growth does not affect higher education. This unidirectional causality relationship can be explained that the economic growth that occurs does not directly increase the overall income of the community, meaning that the positive impact of growth can only be enjoyed mostly by a group of high-income people. The result of this economic condition is the people's purchasing power, especially for the education sector, namely increasing education to a higher level in tertiary institutions, which is still very limited.

The current conditions in Indonesia indicate economic inequality in society, especially the ability of each parent to provide a better education for their children to higher education, which tends to only be done by parents or people who have an income above the average ability. In investing in the education sector, in other words, economic growth in Indonesia does not affect school enrollment for higher education. The fact that currently occurring in Indonesia is based on the results of data estimation, has deviated from the concept of the final goal of development as emphasized by the United Nations Development Program (UNDP) since the 1990s, where there are 4 (four) main keys in development which are essentially efforts complete human development aimed at creating productivity, equality, sustainability and empowerment. The role of economic growth as the principal means to achieve the ultimate goal of development and focus on increasing the value of the Human Development Index (HDI) in Indonesia has not yet been realized.

\section{CONCLUSIONS}

This study examines the reciprocal relationship or causality between education and economic growth in Indonesia during the period 1980-2017. Estimation of higher education data which is proxied by the number of students in higher education and economic growth data concludes the results of the analysis of the causality of the two research variables that there is a unidirectional causality from higher education to Indonesia's economic growth during the study period 1980-2017. Higher education positively affects growth with a significance level of a (alpha) $10 \%$ in lag 1 , meaning that the impact of adding or changing higher education school enrollment will affect growth in the next 1 year but not vice versa. In other words, the results of data estimation also show that growth does not affect school enrollment for higher education during the study period.

The policies that can be taken based on the results of this study are as follows: (1) Investments in education, especially higher education, should involve a lot of stakeholders in the preparation of education sector development planning; (2) The subsidy policy can be applied especially for higher education or vocational levels as an effort to encourage increased productivity of the workforce or educated human resources; (3) The government is obliged to maintain economic stability and encourage people to create savings so that its accelerated effect can increase people's purchasing power in the education sector; (4) The portion of the $20 \%$ APBN for the education sector is maintained and its use must be closely monitored, especially the budget for higher education, so as not to cause more complex problems in the function of the state budget allocation.

\section{REFERENCE}

Apergis, N., \& Poufinas, T. (2020). The role of insurance growth in economic growth: Fresh evidence from a panel of OECD countries. The North American Journal of Economics and Finance, 53, 101217. https:/ doi.org/10.1016/j.najef.2020 101217

Kruss, G., McGrath, S., Petersen, I., \& Gastrow,M.(2015).Highereducation 
and economic development: The importance of building technological capabilities. International Journal of Educational Development, 43, 22-31. https://doi.org/10.1016/j. ijedudev.2015.04.011

Marginson, S. (2018). Higher education, economic inequality and social mobility: Implications for emerging East Asia. International Journal of Educational Development, 63, 4-11. https://doi.org/10.1016/j. ijedudev.2017.03.002

Mariana, Dragoescu Raluca. (2015). Education As A Determinant Of The Economic Growth. The Case Of Romania. Procedia-Social and Behavioral Sciences 197. Elsevier Ltd: 404-412.

Mazzarisi, P., Zaoli, S., Campajola, C., \& Lillo, F. (2020). Tail Granger causalities and where to find them: Extreme risk spillovers vs spurious linkages. Journal of Economic Dynamics and Control, 121, 104022. https://doi.org/10. 1016/j.jedc.2020.104022

Pelinescu, E. (2015). The Impact of Human Capital on Economic Growth, Procedia Economics and Finance, 22, 184-190.

Salman, M., Long, X., Dauda, L., \& Mensah, C. N. (2019). The impact of institutional quality on economic growth and carbon emissions: Evidence from Indonesia, South Korea and Thailand. Journal of Cleaner Production, 241, 118331. https://doi.org/10.1016/j. jclepro.2019.118331

Saepudin, Tete. 2013. Pertumbuhan Modal ManusiaDanPertumbuhanEkonomi Antar Daerah Di Indonesia. Semnas Fekon: Optimisme Ekonomi Indonesia2013, Antara Peluang dan Tantangan. 21-38.

Solaki, Melina. 2013. Relationship Between Educationan GDPGrowth:ABi-variat
Causality Analysis for Greece. International Journal of Economic Practices and Theories. 3,2, 133-139.

Truong, T. H., Ogawa, K., \& Sanfo, J.-B. M.B. (2021). Educational expansion and the economic value of education in Vietnam: An instrument-free analysis. International Journal of Educational Research Open, 2-2, 100025. https://doi.org/10.1016/j. ijedro.2020.100025

Vaduva, S., Echevarria-Cruz, S., \& Takacs, J. (2020). The economic and social impact of a university education upon the development of the Romanian tourism industry. Journal of Hospitality, Leisure, Sport \& Tourism Education, 27, 100270. https://doi.org/10.1016/j. jhlste.2020.100270

Wang, YingandShashaLiu.2016. Education, Human Capital and Economic Growth: Empirical Research on 55 CountriesandRegions(1960-2009). Theoretical Economics Letters, 6, 347-355. 